\title{
MASTER
}

C00-0003-15

Dist. Category UC-90c

\section{PROTOTYPE PILOT PLANT OPERATION SYNTHANE PROCESS}

\author{
CONTRACTOR MONTHLY ACTIVITY REPORT NO. 38 \\ FOR THE PERIOD \\ OCT. 1 - OCT. 31,1977 \\ THE LUMMUS COMPANY \\ BLOOMFIELD, N.J. 07003 \\ LUMMUS JOB NO. 7849
}

DATE PUBLISHED

NOVEMBER 1977

PREPARED FOR THE UNITED STATES

DEPARTMENT OF ENERGY

UNDER CONTRACT N0. EY-76-C-02-0003.*000 


\section{DISCLAIMER}

This report was prepared as an account of work sponsored by an agency of the United States Government. Neither the United States Government nor any agency Thereot, nor any of their employees, makes any warranty, express or implied, or assumes any legal liability or responsibility for the accuracy, completeness, or usefulness of any information, apparatus, product, or process disclosed, or represents that its use would not infringe privately owned rights. Reference herein to any specific commercial product, process, or service by trade name, trademark, manufacturer, or otherwise does not necessarily constitute or imply its endorsement, recommendation, or favoring by the United States Government or any agency thereof. The views and opinions of authors expressed herein do not necessarlly state or reflect those of the United States Government or any agency thereof. 


\section{DISCLAIMER}

Portions of this document may be illegible in electronic image products. Images are produced from the best available original document. 
This report was prepared as an account of work sponsored by the United States Government. Neither the United States nor the United States Department of Energy, nor any of their employees, nor any of their contractors, subcontractors, or their employees makes any warranty, express or implied, or assumes any legal liability or responsibility for the accuracy, completeness, or usefulness of any information, apparatus, product or process disclosed, or represents that its use would not infringe privately owned rights.

Printed in the United States of America

Available from

National Technical Information Service (NTIS)

U. S. Department of Commerce

5285 Port Royal Road

Springfield, Virginia 22161

Price: Printed Copy $-\$ 4.00$

Microfiche $-\$ 3.00$ 
Mr. Harold N, Miller, Director

Contracts Management office

U. S. Department of Energy

9800 South Cass Avenue

Chicago, I1linols 60439

Dear Mr. Miller:

SUBJECT: CONTRACTOR MONTHLY ACTIVITY REPORT NO, 38

for the period covering October 1-31, 1977

Report No. C00-0003-15 covers activities conducted by The Lumus Company at the Synthane Prototype Pilot Plant in Bruceton, Pa., under DOE Contract No. EY-76-C-02-0003.*000.

Very truly yours,

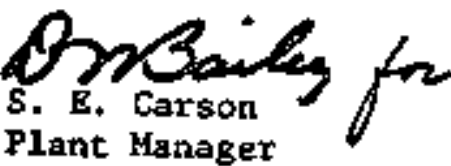

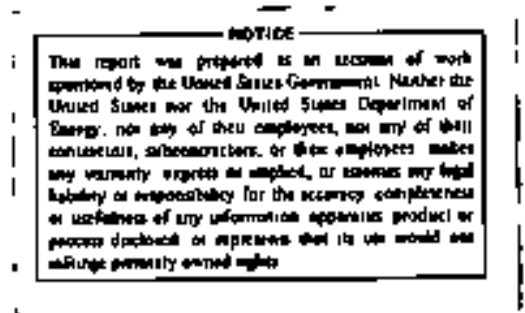

/ce 


\title{
PROTOTYPE PILOT PLANT OPERATION SYNTHANE PROCESS
}

\author{
MONTHLY ACTIVITY REPORT NO. 38 \\ FOR THE PERIOD \\ DCTOBER $1-31,1977$
}

$$
\operatorname{co0}-0003-15
$$

\section{ABSTRACT}

Three attempts were made to operate the pretreater continuously in October using Illinois No. 6 coal, but each ended after a short operating period wth coal agglotaerating in the vessel. Procedures were varted during these tests in an attempt to achieve operability. The first two attempts were made using carbon dioxide to transport the cogl fiom the Petrocarb System to the pretreater, and the third attempt was made using high pressure steam. The use of steam as the transport medium was the most successful. The run was terminated when the coal feed stopped due to condensation of the steam in the line. When the pretreater was opened after this run, the vessel contained some agglomerated coal but most of the pretreater bed was free flowing and pretreated.

Plans are underway to fabricate a temporary supertheacer and acquire a permanent steam superheater for coal transport with steam. Additional tests with carbon dioxide as the transport medfum will continue until a superheater is installed.

\section{INTRODUCTTON, PROJECT OBJECTIVE, AND ACTIVITY SUMMARY}

This report is a presentation of the work accomplished during October 1977 at the Synthane Prototype Research Pilot Plant. The Plant is operated by The Lumuus Company for the U. S. Department of Energy which was inttlated under Contract H036030. by the U. S. Department of Interior, U. S. Bureau of Mines, and was transferred to DOE as Contract (36-2) * .0003 and subsequently renumbered to Contract $5 \mathrm{Y}-76-\mathrm{C}-02-0003 . * 000$. This report represents the $38 \mathrm{th}$ month of progress.

The objective of this Contract is to obtain definitive process information sufficient for commercial design purposes on the conversion of coal to pipeline quality gas. This objective is țo be accomplished through the execution of experimental and developwental operation programs in the Government-owned Synthane Pilot Plant, located in South Park Township, Allegheny County, Pennsylvania.

The following is a sumary of activicies during October:

1. The pretreater was operated using Illinois No. 6 coal on October 25 , 29 and 31 . The runs conducted on October 25 th and 29 th were made using carbon dioxide as the coal transport medium. The runs were stopped after approximately one hour of operation due to agglomeration in the pretreater. The run conducted on 0ctober 31 used steam as the coal transport mediun and was the most successful to date. This run was curtailed after nearly two hours of operation because 
the outlet of the Petrocsrb System plugged with wet coal. The pretreater when opened contalned some agglomerated coal, but in general, the bed was free flowing end pretreated. The steam which is avallable, is only $720^{\circ} \mathrm{P}$ and does not have enough superheat when combined with eoal feed to prevent condensation in the feed 1ine. A major effort is now being undertaken to fabricate a temporary steam superheater and purchase a permanent superheater in order to transport the coal with steam. It is also planned to infect oxygen with the steam in order to achieve some pretreatment in the line before the coal enters the pretreater.

2. Enclosing of the structure is presently requiring a major effort. This project is estimated to be $60 \%$ completed. The structure will be enclosed from the second through the seventh floors, and from the 11th to the 13th flooss in an effort to provide more operabiificy during the winter months.

3. The Benfleld and Stretford Units are currently in circulation and are ready for operation.

\section{ACTIVITIES_DURING THE MONTH}

\section{OPERATIONS}

1. The gasifier, pretreater and gas scrubbing area were shut down and opened for inspection on October 1. The Plant then remalned down for 21 days in order to remove obstructions in piping that were interfering with enclosing the structure, and to install an oxyen Iine into the coal transport line such that oxygen can be injected into the coal transport line with the transport gas. Modifications also included extending the cyclone dip leg to the cone line and replacement of check valves in the Petrocarb System.

The gasiffer and the pretreater were closed and heatup was started on October 22. Steam and $\mathrm{CO}_{2}$ circulation were started on 0ctober 24. A coal bed was established in the pretreater on october 25 and the bed heated to $800^{\circ} \mathrm{F}$. Feed was then restarted per the procedure tsing carbon dioxide as the transport mediut. Shutdown was necessary after 1-1/2 hours due to agglomeration in the pretreater.

A declsion was then made to try to transport coal with steam rather than carbon dioxide even though the pretreater was plugged. Coal was then transported with $s$ tean successfully for two hours af ter which the pretreater was shut down and opened for cleaning. Gasifier was also depressured in order to repair a packing gland leak on the char cooler slot valve. When the slot valve repairs were completed. the system was repressured and steam circulation vas established.

The pretreater when opened, vas found to be halt full of soft agglomerated coal. The feed pipe was then modified by lowering the feed line to the botton of the cone. A splash plate was installed below the feed line to divert the feed. The pretreater was closed and pressure tested on October 27. A leak developed in the steam side of the $\mathrm{CO}_{2}$ heater which then delayed the next pretreater run. 
The next run was conducted on 0ctober 29. During this run, it was declded to modify the procedure by slowly iatroducing oxygen. With this procedure, the 1ntial bed tempersture was heated at 5 to $7^{\circ} \mathrm{P}$ per minute to $800^{\circ} \mathrm{F}$ and then held for 15 qinutes before reintroducing feed. Carbon dioxide was again used for coal transport. Shortly after restarting coal and oxygen feed, a high differential pressure between the gasifier and char cooler tripped coal and oxygen feed to the pretreater. Even though the pretreater operation was resuided wfthin a minute, the interruption in oxygen feed may have helped cause the agglomeration which shortly thereafter occurred in the pretreater, and resulted in the termination of the run.

On October 31 , another pretreater run was attempted. However, this time steam was used to transport the coal to the pretreater. During this run, the pretreater was heated to $800^{\circ} \mathrm{F}$ with oxygen and carbon dioxide at which time the carbon dioxide transport bas was changed to steam. Oxygen was then started to the transport line imnediately followed by coal. Operation continued for 2 hours when coal feed was lost due to plugging of the transport line with wet coal under the primary injector of the Petrocarb systern. The pretreater was opened and was found to contain some small pleces of agglomerated coal and mostly free-flowing coal which was pretreated by FSI. analysis.

2. Inttial charging of chemfcals to the Stretford Unit began on october 9, and was completed on 0ctober 14. The Stretford Jnit is presently circulating at destred solution strength ready for operation.

3. Benfield Unit circulation started on October 20 and continues to circulate through the end of the month with no operating problems.

\section{TECHNICAL}

1. Calculations show that the equilfbrium temperature in the coal transport line of a mixture of $6000 \mathrm{SCFH} \mathrm{CO}_{2}$ at $550^{\circ} \mathrm{F}$ and 4000 lbs/hour of coal at $150^{\circ} \mathrm{F}$ as presently operated will be about $200^{\circ} \mathrm{F}$. If hot $\mathrm{C}_{2}$ is also used to the primary injector, the maximum temperature of the feed will be about $250^{\circ} \mathrm{F}$. As it is our understanding that the ignition temperature of coal with oxygen is between $350^{\circ} \mathrm{F}$ and $450^{\circ} \mathrm{F}$, the use of oxygen in the lift line with carbon dioxide transport should have no advantage. The tow feed tenperature, caused by using carbon dioxide as the transport medium, is believed to be causing agglomeration in the pretreater.

It has therefare been decided to design a steam superheater for $1100^{\circ} \mathrm{F}$ stean for the transport of coal from the Petrocarb System. It was agreed that the design basis for the superheater stall be for $1000 \mathrm{psig}$ and $600 \mathrm{psig}$ gasifier operations vith some overdesign. The design requirements have been ișsued to the Plant Engineering Group for detalling and purchasing.

2. A kinetic model for the gasifier has been written. This model takes Into account the properties of fluldized beds, rates of 
varlous reactions, etc. We are presently reviewing literature to obtain rate constants for the various reactions. We have been able to obtain expresstons to determine various reaction rate constants for the gasiffer klnetic model. Sowe form of expressing the reaction rate for methane producing reactions is yet to be obtained.

3. A graph of stean decomposition versus gasifier bed temperature has been plotted using the stean to coal ratio as a parameter. The plot Indicates that the stean decomposition incteases with increasing temperature. A temperature of about $1800^{\circ} \mathrm{F}$ is estimated to be required to obtain the $25 \%$ to $30 \%$ steam conversion assumed in the original gasifier design.

The study of the effect of total oxidant, defined as oxygen in steam plus elemental oxygen, on carbon conversion, and gas yields has once again confirmed our earlier conclusions. This study indicates the relative unimportance of the residence titie on conversions and gas ylelds. A menorandum on this subject is being prepared.

4. The overall and elemental material balance calculations for the gastfler have been completed, and these calculations will be completed by the computer. A prelininary format for reporting the balances has been prepared.

5. As a result of a study of the Benfield Systen, we have concluded that the 2-inch Intalox saddles used as packing in the tower may be overloaded when processing Illinois No. 6 coal. A memorandum discussing our recommendations has been released.

6. Representatives of the Pennsylvania Department of Environmental Resources were on site for a meeting in which we were seeking modifications to our NPDES permit. We have requested to allow the blowdown water from the high pressure boiler to be a ph of 10 as opposed to the ariginal NPDES permit wherein we specified that this blowdown would have a $\mathrm{pH}$ of 9 . Operating experience with our boilers dictates that the boiler water must be maintained at a pH of 10 for correct phosphate control.

\section{ENGINEERING}

1. The preliminary design for the gasifier overhead sampling system was released for consideration.

2. Final design has been coupleted for the installation of the co Monttoring System in the structure.

3. The design for the Wills Choke Valve modffications was released to Maintenance. A choke was modified using the nesly designed double orifice. Preliminary tests were run on october 21 to check the flow rate and controllability of the net trim.

4. The final design for the modifications to the pretreater feed line was released to Maintenance. 
5. Preliminary design for fabrication of a 3-inch slot valve was released for consideration. The proposed design of the 3-inch slot valve makes use of a sash welght to maintain closure of the slot valve tlapper.

6. The final design for the installation of double block and bleed valves for the low pressure boiler pilots was released to Maintenance.

7. The final design to converc the gasifier startup heater from fuel oil to propane has been completed.

8. The preliminary design for caustic injection to the 48-inch storm sewer was released for consideration. This project has been prepared because acid mine water is destroying the matn sewer Iine through the Plant.

9. A review reeting was held to consider modifications to the shower and locker facilities. It has been proposed to supply all clothing including jackets, work suits, thermal underwear, socks and shoes and to provide a clean and dirty room.

10. The final design to redirect the char cooler outlet steam to thermal oxidizer water guns was released for approval.

11. A review meeting was held with the Technical Department to discuss the design and scope for installation of a superheater for utilizing steam rather than carbon dioxide as the medium for coal transport to the pretreater. The initial scope considers installation of an electrical steam superheater to provide $1100^{\circ} \mathrm{F}$ steam. The modification also required that the existing transport line be increased from one to two inches.

12. All drawings have been completed for the routing of a fire alarm indicator tn the Control Room from the sprinkler systems in the Warehouse and the Modular Building. The final design will be issued during Novenber. This is one of the projects requested by the DOE Fire and Safery Audit.

\section{MAINTENANCE}

1. During the month of October, 337 work orders were completed. A backlog of 141 work orders was carried through to November.

2. Najor jobs worked during the month were as follows:

a. The Stretford Desulfurtzation Untt was prepared for operation.

b. The pretreater wss opened, cleaned and closed three times. The gastfier and char cooler were opened, cleaned and closed once during october. Two modifications were made to the pretreater coal feed inler.

c. The thermal oxtdizer expertenced a refractory fallure above 
the mankay. The arch partially collapsed and required extenstve repatrs using $\mathrm{C}-\mathrm{E}$ refractories.

d. Considerable effort and time were spent on relocating electrical condult, high pressure steam lines, and process piping in order to provide clearances for the structure enclosure project.

e. A concentrated effort is being made to complete the steam condensate return systep before cold weather arrives. This effort is required $8 \mathrm{~s}$ a result of the Berfield and the Stretford Units being operational and their increased use of stean.

f. An oxygen line was connected into the coal transport line to the pretreater. This modification will allow oxygen to be injected with the transport gas to the pretreater.

g. The electric traciog on the coal transport line from the ground floor to the tenth floor falled. The heat transfer cement appears to have deteriorated causing inadequate heat transfer resulting in a hot spot. A 3-citcuit system was installed in place of the single circuit system.

\section{SAFETY}

1. There were no reportable anjuries for Lumbe employees in October. Lumbus personnel have now worked 41 months without any last-time accidents.

2. Safety data sheets are being prepared for all chemicals used in the Chentical Laboratory.

FLANT VISITORS DURYNG THE MONTH

Representatives fron C. F. Braun, Alhambra, California. Fossil Energy Sentor Staff Metbers from the Department of Energy. Representatives from office of Management and Budget, President's Domestic Policy Staff, Department of Interior, office of Sclence and Technology Policy of the White House, Environmental Protection Agency, and the Council of Environmental Quality.

Mr. Brian Robson from the National Coal Board, England.

Mr. Jín McGee from Gilbert Associates, Morgantown, West Virginia. Representatives from the Department of Environmental Regources. Mr. Carlos Martinez from Colombia Ofl and Gas.

Visttors from Yugoslavia.

Dr. R. Yamamura from Coal Minting Research Center, Japan.

Mr. H. Konatsu from Japan Coal Aasociation.

Mr. A. Kamono from Matsushima Coal Mining Co., Ltd.

Representatives from International Gas Technology.

Dr. Langhoff from Ruhrkohle $E_{g}$, Essen, Germany.

Dr. Wolowsk1 from GW, Bottrop, Germany.

Mr. Schlupp from Steag, Essen, Germany.

Dr. Wien from Steag, Essen, Germany. 


\section{PROBLEMS}

S1x attempts have been made thus far to operate. the pretreater. In all cases, the operation had to be curtailed after only a few hours of operation because of agglomeration in the pretceater. In five runs, carbon dioxide has been utilized for coal transport and duriag one run, stean was utilized.

Procedures require partial loading of the pretreater with coal and then heating with oxygen to $700^{\circ} \mathrm{F}$ and in later tests, to $800^{\circ} \mathrm{F}$ before reintroducing coal feed. Each time coal feed is reintrodtced using carbon dioxide as the transport gas, the bed temperatures dropped and the bed imediately thereafter agglonerated.

During the laet test, high pressure steam was used to trangport the coal. After 2 hours, the feed line eventually plugged with wet coal because the gteam used does tot contain enough superheat to prevent condensation in the line. Following this run, the pretreater was opened and although there was some pieces of agglomerated coal in the vessel, most of the material was free flowing and was pretreated by FSI analygis.

It appears that if superheated stean were available for coal transport, the pretreater would operate satisfactorily. A superheater, therefore, Is being designed on a priortty basis. A temporary superheater will be fabricated until a permsnent unit can be acquired. Uncil such time that the temporary superheater is completed, tests will continve with carbon dioxide as the transport medium in order to investigate other operatiog possibilities.

\section{v. PLANS}

1. Continue to operate the pretreater and attempt to resolve the aggtom meration problems.

2. On a priority basis, design and purchsse a superheater to provide high pressure steam at $1000^{\circ} \mathrm{F}$ for transporting the coal from the Petrocarb System to the pretreater.

3. Continue taboratory studies of agglomeration in an attempt to obtaln more information on condittons that promote agglomeration. 


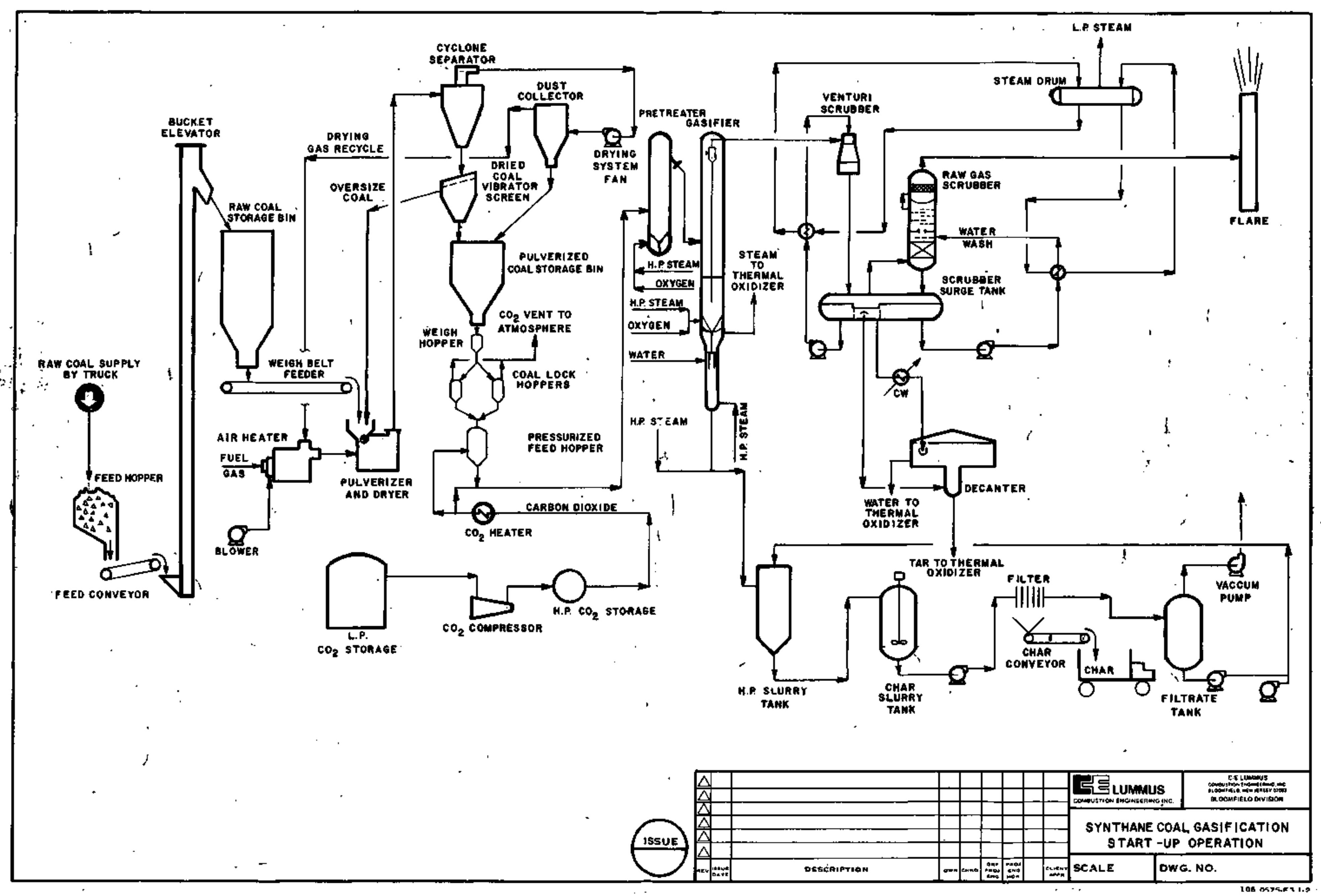

